\title{
Uptake and fate of diarrhetic shellfish poisoning toxins from the dinoflagellate Prorocentrum lima in the bay scallop Argopecten irradians
}

\author{
Andrew G. Bauder*, Allan D. Cembella, V. Monica Bricelj, Michael A. Quilliam \\ Institute for Marine Biosciences, National Research Council, Halifax, Nova Scotia B3H 3Z1, Canada
}

\begin{abstract}
Bivalve molluscs can acquire diarrhetic shellfish poisoning (DSP) toxins via ingestion of toxigenic dinoflagellates. The dynamics and fate of DSP toxins were investigated in the bay scallop Argopecten irradians exposed to cells of the epibenthic dinoflagellate Prorocentrum lima, a known producer of DSP toxins, in controlled laboratory microcosms. Toxin parameters determined were uptake and detoxification rates, and anatomical compartmentalization. Toxins in tissue and algal extracts were analyzed by liquid chromatography-mass spectrometry (LC-MS). No mortalities occurred and feeding inhibition was not observed for juvenile and adult bay scallops during the $2 \mathrm{wk}$ exposure to P. lima cells. Clearance rates were similar for scallops exposed to equivalent biovolume cell concentrations of toxigenic $P$. lima and the non-toxic diatom Thalassiosira weissflogii; however, absorption efficiency of organic matter was significantly lower with a diet of $P$. lima than $T$. weissflogii. Although DSP toxin concentrations in viscera of bay scallop exceeded commonly accepted regulatory levels ( $0.2 \mathrm{\mu g} \mathrm{g}^{-1}$ whole tissue) within $24 \mathrm{~h}$ of exposure to $P$. lima, after $2 \mathrm{wk}$ of exposure total DSP toxin retained in scallop tissues was $<1 \%$ of the total toxin ingested over the same period. Most of the total toxin body burden was in the viscera $(76 \%)_{\text {; }}$ however, in adult scallops a significant portion was associated with gonadal tissue $(12 \%)$. Toxin levels were relatively low in gill, mantle and adductor tissue $(<12 \%$ of total toxin body burden). During the depuration period, rapid release of DSP toxins from scallops indicated that toxins were poorly bound to all tissues, with the exception of the viscera. Detoxification of viscera consisted of a rapid loss of weakly bound toxin components within the initial $3 \mathrm{~d}$ of depuration, followed by a much slower release of the remaining toxin at a rate of $8.4 \% \mathrm{~d}^{-1}$.
\end{abstract}

KEY WORDS: DSP · Okadaic acid · Prorocentrum lima $\cdot$ Argopecten irradians - Bay scallop · Phycotoxin · Dinoflagellate

\section{INTRODUCTION}

Diarrhetic shellfish poisoning (DSP) poses a serious public health risk and constitutes an economic threat to harvesters of cultured and wild shellfish worldwide, especially in Japan and Europe (Shumway 1990). Consumption of shellfish contaminated by DSP toxins results in symptoms similar to severe gastroenteritis, including diarrhea, nausea, abdominal cramps and vomiting. The lipophilic polyether compounds associ-

${ }^{*}$ E-mail: abaude@po-box.mcgill.ca ated with the DSP toxin complex (Quilliam 1995, Wright \& Cembella 1998), including okadaic acid (OA) and its dinophysistoxin (DTX) derivatives (Fig. 1), induce diarrheic symptoms by acting as potent protein phosphatase inhibitors in metabolic processes (Aune \& Yndestad 1993). Furthermore, it has recently been proposed that OA and DTX1 are powerful cancer promoters and that chronic exposure to these toxins could stimulate the growth of gastrointestinal tumours (Aune \& Yndestad 1993).

Bivalve molluscs acquire DSP toxins by ingesting dinoflagellates from the water column and, perhaps, 


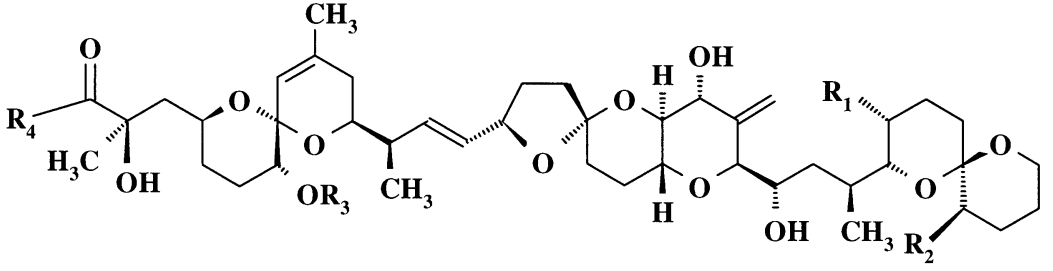<smiles>[Y]=[In]</smiles>

\begin{tabular}{ccccl}
\hline $\boldsymbol{R}_{\boldsymbol{1}}$ & $\boldsymbol{R}_{\boldsymbol{2}}$ & $\boldsymbol{R}_{\boldsymbol{3}}$ & $\boldsymbol{R}_{\mathbf{4}}$ & \\
\hline $\mathrm{CH}_{3}$ & $\mathrm{H}$ & $\mathrm{H}$ & $\mathrm{OH}$ & Okadaic acid (OA) \\
$\mathrm{CH}_{3}$ & $\mathrm{CH}_{3}$ & $\mathrm{H}$ & $\mathrm{OH}$ & DTX1 \\
$\mathrm{CH}_{3}$ & $\mathrm{H}$ & $\mathrm{H}$ & $\mathrm{X}$ & OA diol ester (OADE) \\
\hline
\end{tabular}

Fig. 1. Structures of okadaic acid (OA), dinophysistoxin-1 (DTX1) and a diol ester of OA (OADE). The latter, which has the OA carboxyl function conjugated to an aliphatic diol group, is present in Prorocentrum lima and can also accumulate in scallops. $\mathrm{R}_{1}=\mathrm{CH}_{3}, \mathrm{R}_{2}=\mathrm{H}$ or $\mathrm{CH}_{3}, \mathrm{R}_{3}=\mathrm{H}, \mathrm{R}_{4}=\mathrm{OH}$ or $\mathrm{X}$

considered because these may be altered by exposure to toxigenic dinoflagellates. Species-specific differences in short-term feeding responses to toxigenic dinoflagellates (e.g. Alexandrium spp.) responsible for paralytic shellfish poisoning (PSP), have been previously demonstrated (Shumway \& Cucci 1987). Bivalve responses to PSP toxin-producing dinoflagellates at high cell concentrations included shell-valve closure, reduced clearance rates and increased pseudofeces production. Shumway et al. (1985) also argued that bivalves can use post-ingestive sorting mechanisms, such as decreased digestion and absorption rates, to limit assimilation of toxins into tissues. Although it has been hypothesized that similar protective feeding mechanisms are employed by shellfish to prevent accumulation of DSP toxins (Haamer et al. 1990), this hypothesis has only been evaluated in mussels (Pillet \& Houvenaghel 1995, Svensson \& Forlin 1998).

via feeding on resuspended benthic material. The known dinoflagellate producers of DSP toxins include several planktonic species of the genus Dinophysis and a few epibenthic Prorocentrum species (Yasumoto 1990, Andersen 1996). Most of the reported DSP events have implicated Dinophysis spp. as the causative dinoflagellates (Kat 1985, Hageltorn 1989, Gago et al. 1991). A few incidents have been circumstantially linked to the presence of $P$. lima (Yasumoto et al. 1989, ICES 1992, Quilliam et al. 1993, van Egmond et al. 1993), but most of this evidence has been inconclusive. Lawrence et al. (1998) recently confirmed the presence of toxigenic $P$. lima cells growing as part of the epiphytic flora on mussel culture lines in eastern Nova Scotia, Canada.

There is a critical gap in knowledge of species-specific kinetics and metabolism of DSP toxins in shellfish (van Egmond et al. 1993), including rates of uptake and detoxification, anatomical compartmentalization and pathways of biotransformation. Although several reports have related the incidence of DSP toxins in shellfish to phytoplankton blooms (Rodriguez et al. 1989, Zhao et al. 1993, Gilgan et al. 1994), few studies have attempted to describe the uptake kinetics of DSP toxins by bivalve molluscs, either under controlled laboratory conditions (Pillet et al. 1995, Svensson \& Forlin 1998) or in field populations (Haamer et al. 1990, Marcaillou Le-Baut et al. 1993a, Reguera et al. 1993).

In an investigation of phycotoxin kinetics in shellfish, physiological feeding processes of the species must be
Field studies have provided useful information concerning in situ toxin concentrations in shellfish (Marcaillou-Le Baut et al. 1993a, Haamer 1995), but the kinetics of DSP toxins in bivalves can only be approximated in the field due to lack of control of environmental variables such as water temperature, phytoplankton concentration and cellular toxin content. By exposing bivalves to simulated 'blooms' of toxigenic dinoflagellates in controlled laboratory microcosms, a more precise determination of physiological feeding parameters leading to the accumulation of toxins in shellfish tissue can be achieved (Bricelj et al. 1990). An additional advantage of laboratory feeding studies is that bivalves can be more closely monitored for detrimental effects caused by exposure to toxic dinoflagellates (Shumway \& Cucci 1987, Bardouil et al. 1993).

There is a critical lack of information on the effects of DSP toxin-producing microalgae on scallops, including cultured and wild populations. Of particular interest is the bay scallop Argopecten irradians, which has become a tremendously successful cultured species in China (Chew 1990) after being introduced from the eastern USA, where it is harvested both in culture and from the wild fishery (Rhodes 1991). New markets for scallops are encouraging the sale of 'half-shell' (whole animal) and 'roe-on' (gonad attached to adductor) products rather than just the adductor muscle, which has been the only part of the scallop traditionally consumed in North America (Cembella et al. 1994).

The rate at which phycotoxins are released from contaminated shellfish is also of question. Although 
data from previous studies suggest that sea scallops Placopecten magellanicus and Japanese scallops Patinopecten yessoensis are prone to retain PSP toxins for extended periods (Shumway \& Cembella 1993, Bricelj \& Shumway 1998), information is scarce concerning detoxification rates of DSP toxins from scallops (Tazawa et al. 1989, Kikuchi et al. 1992). Moreover, the unique chemistry of DSP toxins suggests that simple extrapolation based upon results for PSP toxins may not be possible.

The objective of the present study was to examine rates of feeding and DSP toxin kinetics in bay scallops Argopecten irradians exposed to DSP-toxigenic cells of Prorocentrum lima as a food source in a controlled laboratory environment.

\section{MATERIALS AND METHODS}

Algal culture and scallop source. The epibenthic marine dinoflagellate Prorocentrum lima, isolated from Mahone Bay, Nova Scotia, Canada (Strain PA), was cultured in modified K-medium (Keller et al. 1985) prepared from filtered $(1 \mu \mathrm{m})$ UV-sterilized natural seawater. Dinoflagellates were grown in unialgal batch cultures contained in 2.81 polycarbonate Fernbach flasks on a 14:10 h light:dark photocycle, at an incident photon flux density of $90 \mu \mathrm{mol}$ photons $\mathrm{m}^{-2} \mathrm{~s}^{-1}$ (QSL-100 $4 \pi$ sensor, Biospherical Instruments), and a temperature of $17^{\circ} \mathrm{C}$ (Bauder 1997).

For feeding experiments, cultures of Prorocentrum lima inoculated in staggered sequence were harvested at the same point of late exponential growth

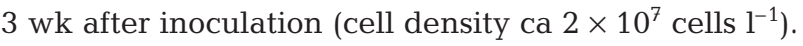
The diatom Thalassiosira weissflogii (isolated from Long Island, New York, USA), which is readily cleared and assimilated by bay scallops (Bricelj \& Kuenstner 1989), was used as a non-toxic food source during acclimation and as a control diet. T. weissflogii was cultured on f/2 growth medium (Guillard \& Ryther 1962) supplemented with silicate in 3001 fiberglass columns at $17^{\circ} \mathrm{C}$ and at an incident photon flux density of $600 \mu \mathrm{mol} \mathrm{m} \mathrm{m}^{-2} \mathrm{~s}^{-1}$.

Juvenile bay scallops were obtained from a hatchery in Ship Harbour, Nova Scotia. Pre-reproductive adult bay scallops (shell height, $\mathrm{SH}_{1}=30$ to $40 \mathrm{~mm}$ ) were acquired from a bottom grow-out site in Little Harbour, Nova Scotia (Little Harbour Fisheries). Scallops were held in upwellers at $17^{\circ} \mathrm{C}$ in flow-through raceways supplied with unfiltered seawater supplemented with Thalassiosira weissflogii.

Feeding experiments. Since feeding physiology and behaviour can vary between juveniles and adults, both juvenile and adult bay scallops were used to examine the effects of exposure to Prorocentrum lima cells on feeding activity and DSP toxin kinetics. Short-term $(<24 \mathrm{~h})$ experiments were used to determine clearance and ingestion rates, whereas toxin kinetics and postingestive feeding activity were examined in long-term experiments $(>2 \mathrm{~d})$. Toxin exposure periods were limited to a maximum of $14 \mathrm{~d}$, since previous studies indicated that maximum PSP toxin concentrations in bivalves were recorded within 2 wk of exposure to toxic algae (Bricelj et al. 1990, 1991).

Short-term clearance rates: Measurements of clearance rates (CR) were conducted to determine the feeding activity of bay scallops exposed to DSP toxin-producing Prorocentrum lima cells (equivalent spherical diameter, $\mathrm{ESD}=35 \mu \mathrm{m}$ ) and to equivalent biovolume concentrations of Thalassiosira weissflogii $(\mathrm{ESD}=$ $12 \mu \mathrm{m})$.

$\mathrm{CR}$ of juvenile scallops were measured from the depletion of algal cells over time in closed systems. Scallops (mean $\mathrm{SH}=12.71 \mathrm{~mm}, \mathrm{SE}=0.48$; mean wet soft tissue wt $=166.75 \mathrm{mg}, \mathrm{SE}=11.65$ ) were divided into 5 replicate pools, each containing 5 individuals. Each pool was placed in $500 \mathrm{ml}$ glass beakers containing algal suspensions at an initial cell concentration of either 5000 cells $\mathrm{ml}^{-1}$ of Thalassiosira weissflogii or 300 cells ml ${ }^{-1}$ of Prorocentrum lima. Two other beakers containing algal suspension without scallops were used as controls for each experiment. The algae were kept in suspension by bubbling air through an airstone placed in each beaker. Dissolved oxygen was not measured during the experiment since the beakers were supplied with constant aeration. Samples of the suspension $(5 \mathrm{ml})$ were taken from each beaker at the beginning of the exposure period and after $20 \mathrm{~min}$ for microscopic enumeration. Scallops were sacrificed to determine total wet tissue weight. CR were estimated according to the equation: $\mathrm{CR}=\ln \left(C_{0} / C_{1}\right) \times V / t \times n^{-1}$ (Coughlan 1969), where $C_{0}$ and $C_{1}$ are the initial and final cell density, respectively, $V$ is the volume of suspension, $t$ is the time interval and $n$ is the number of scallops. CR were converted to weight-standardized rates $\left(C R_{\mathrm{S}}\right)$ for a scallop of $1 \mathrm{~g}$ total wet body weight according to the equation: $C R_{\mathrm{S}}=C R_{\mathrm{e}} / W_{\mathrm{e}}{ }^{b}$, where $C R_{\mathrm{e}}$ and $W_{\mathrm{e}}$ are the CR and total wet tissue weight of the experimental animal, respectively, and $b$ is the exponent of the allometric equation relating $\mathrm{CR}$ and body size $(=0.75$; Bayne \& Newell 1983).

Flow-through Plexiglas feeding chambers were used to determine the effect of cell concentration on CR and ingestion rates of adult bay scallops using equivalent cell biovolume concentrations of Prorocentrum lima or Thalassiosira weissflogii. Individual adults $(\mathrm{n}=7)$ (mean $\mathrm{SH}=40.34 \mathrm{~mm}, \mathrm{SD}=2.94)$ were randomly placed in parallel chambers. Empty scallop shells were placed in 2 of the chambers during each feeding study, serving as control chambers to ensure that alga cells 
did not settle in the chambers. A high-capacity peristaltic pump (Masterflex) was used to pump the algal suspension from the $100 \mathrm{l}$ stock tank into a $30 \mathrm{l}$ aerated header tank fitted with an overflow valve that maintained a constant volume in the tank. The suspension was gravity-fed from the header tank to the individual feeding chambers via Tygon tubing (i.d. $=20 \mathrm{~mm}$ ) at a constant flow rate of $180 \mathrm{ml} \mathrm{min}{ }^{-1}$.

Scallops were exposed to 6 different cell concentrations of Thalassiosira weissflogii $(860,1200,3730$, $6480,14530,20700$ cells $\mathrm{ml}^{-1}$ ) or equivalent biovolume concentrations of Prorocentrum lima (36, 83, 135, 177, 243, 426 cells $\mathrm{ml}^{-1}$ ). They were allowed to acclimate to each cell concentration for $90 \mathrm{~min}$, at which time samples of algal suspension $(100 \mathrm{ml})$ were taken simultaneously from the outflow of each chamber. Cell concentrations were determined by microscopic enumeration and using an electronic particle counter (Coulter Multisizer) equipped with a $100 \mu \mathrm{m}$ aperture.

CR were calculated according to the equation: $\mathrm{CR}=$ $F \times\left(C_{\text {in }}-C_{\text {out }}\right) / C_{\text {in }}$ (Hildreth \& Crisp 1976), where $F$ is the flow rate in the feeding chambers, $C_{\text {in }}$ is the cell concentration in the inflow (mean outflow of 2 control chambers) and $C_{\text {out }}$ is the outflow cell concentration. Feces and pseudofeces produced were removed with a Pasteur pipette 5 min prior to collection of outflow suspension samples. Scallops were sacrificed to determine the total wet tissue weight and total dry tissue weight after lyophilization.

Long-term feeding: Three separate experiments were conducted to determine DSP toxin uptake patterns in juvenile and adult bay scallops: (1) juvenile bay scallops were exposed to Prorocentrum lima cells for $14 \mathrm{~d}$ to measure toxin uptake rates; (2) adult bay scallops were exposed to $P$. lima cells for $2 \mathrm{~d}$ to examine compartmentalization of toxins in tissues; (2) adult bay scallops were exposed to $P$. lima for $13 \mathrm{~d}$ to measure toxin uptake rates, followed by 3 wk of feeding on non-toxic Thalassiosira weissflogii cells to determine toxin depuration rates.

Toxin uptake in juveniles: Juvenile bay scallops (mean $\mathrm{SH}=19.65 \mathrm{~mm}, \mathrm{SD}=1.55$; mean soft wet tissue $\mathrm{wt}=0.498 \mathrm{~g}, \mathrm{SD}=0.129, \mathrm{n}=99$ ) were held for $14 \mathrm{~d}$ in a recirculating aquarium containing 301 of filtered $(1 \mu \mathrm{m}) \mathrm{UV}$-treated seawater at $17^{\circ} \mathrm{C}$ and $31 \mathrm{ppt}$ salinity. Dissolved oxygen was not measured since the aquarium was supplied with constant aeration. Cultures of Prorocentrum lima were harvested daily and continuously metered from a stock tank into the aquarium with a peristaltic pump, to yield an approximately constant cell density of $10^{5}$ cells $\mathrm{l}^{-1}$. Water was also pumped from the aquarium into a waste tank at the same rate as the inflow to maintain a constant volume of water in the aquarium. Cells were kept in suspen- sion in the aquarium by the action of 2 recirculating pumps mounted on each end and 2 aeration tubes mounted along the bottom of the aquarium. The entire volume of water in the aquarium was exchanged every $2 \mathrm{~d}$ to prevent fouling and re-ingestion of fecal material by the scallops.

Algal cell concentrations in the aquarium were determined by microscopy. The number of cells ingested by scallops in the aquarium was determined each day by calculating the number of cells delivered from the stock tank, the number of cells removed by the exit (waste) flow and the change in cell concentration in the aquarium. Weight-specific ingestion rates were standardized according to the mean wet weight of all scallops used in this study $(0.50 \mathrm{~g}, \mathrm{SD}=0.13, \mathrm{n}=$ 99). Weight-specific values of cumulative toxin ingested (CTI) were determined according to the equation: $\mathrm{CTI}=\mathrm{TCI} \times \mathrm{CTC}$, where TCI is the weight-specific total number of cells ingested, and CTC is the timespecific cellular toxin content. Toxin accumulation efficiency (TAE) was determined by the equation: TAE = TTBB/CTI $\times 100$, where TTBB is the total toxin body burden (as determined by LC-MS).

Replicate $(n=3)$ samples of 3 pooled juvenile scallops were removed at regular intervals from the aquarium for toxin analysis and replaced with marked scallops not previously exposed to Prorocentrum lima to maintain a constant biomass in the tank. For each pool, the tissues were removed and divided into 2 groups: viscera (digestive gland-stomach complex) and all other tissues (including gills, mantle and adductor muscle). Tissues were weighed, quick-frozen with isopropanol/dry ice and kept on dry ice until transfer to the main laboratory (ca 2 to $4 \mathrm{~h}$ ), where they were stored at $-80^{\circ} \mathrm{C}$.

Compartmentalization of toxins in adults: A 2 d feeding study was conducted to determine how DSP toxins are compartmentalized within adult scallop tissues following ingestion of Prorocentrum lima cells. Twenty-four pre-reproductive adult (gonads not fully mature) bay scallops (mean $\mathrm{SH}=38.63 \mathrm{~mm}, \mathrm{SD}$ $=0.50$ ) were exposed to $P$. lima cells (mean cell density $=80$ cells $\mathrm{ml}^{-1}$ ) in an $80 \mathrm{l}$ recirculating aquarium using methods described above. All scallops were removed and divided into 3 pools of 8 scallops at the end of the $2 \mathrm{~d}$ exposure. The following tissues were removed from each scallop: viscera, gonad (including the intestinal loop), mantle, gills and adductor muscle. Metanephridium and heart tissue was included with the viscera. Within each pool, tissues were combined, resulting in triplicate samples of each tissue. Combined tissue pools were weighed, immediately immersed in $4: 1$ (v:w) $80 \%$ aqueous methanol, and stored at $-20^{\circ} \mathrm{C}$ for later toxin extraction and analysis. 
Toxin uptake and depuration in adults: A long-term (13 d) toxin exposure and detoxification study was conducted using pre-reproductive adult bay scallops ( $\mathrm{n}=$ 61 , mean $\mathrm{SH}=38.21 \mathrm{~mm}, \mathrm{SD}=3.89$; mean soft wet tissue wt $=4.68 \mathrm{~g}, \mathrm{SD}=1.22$ ), exposed to Prorocentrum lima in an $80 \mathrm{l}$ aquarium at $17^{\circ} \mathrm{C}$. Three scallops were removed for toxin analysis, with replacement at frequent intervals $(2 \mathrm{~h}$ at beginning of exposure to $2 \mathrm{~d}$ near end of exposure). Scallops were immediately dissected into 3 tissue groups: viscera, gonad (including intestinal loop) and all other tissues (including adductor muscle, mantle and gills). Tissues were weighed and then placed in plastic centrifuge tubes containing 9:1 (v:w) $80 \%$ aqueous methanol and temporarily stored on dry ice $(<6 \mathrm{~h})$. Samples were stored at $-20^{\circ} \mathrm{C}$ until toxin extraction.

Scallops were detoxified for 1 wk by immediate transfer to another $80 \mathrm{l}$ aquarium containing Thalassiosira weissflogii at an approximately constant cell concentration of 2500 cells ml$^{-1}$. After all feces containing intact Prorocentrum lima cells had been voided, the remaining scallops were transferred to a flowthrough seawater raceway supplemented with $T$. weissflogii, from which scallops were sampled for toxin analysis for 2 more weeks. The remaining scallops were removed after $8 \mathrm{wk}$ of detoxification.

$\mathrm{CR}$, fecal deposition rates (FDR), and absorption efficiencies (AE) of the adult scallops were determined after $1 \mathrm{~h}, 3 \mathrm{~d}$ and $8 \mathrm{~d}$ of exposure to Prorocentrum lima cells. The same measurements were also determined for equivalent biovolume concentrations of Thalassiosira weissflogii cells, $1 \mathrm{~d}$ prior to $P$. lima exposure and after $5 \mathrm{~d}$ of detoxification; 7 labeled scallops were removed from the aquarium and placed in flowthrough feeding chambers. Algal suspensions were pumped from a stock tank into the feeding chambers at approximately the same concentration as in the aquarium. After $90 \mathrm{~min}$ acclimation in the chambers, CR were measured. Fecal ribbons produced in each of the feeding chambers were gently removed using a Pasteur pipette and filtered onto preweighed, precombusted $25 \mathrm{~mm}$ Whatman GF/F filters. Samples of $P$. lima and $T$. weissflogii stocks $(15 \mathrm{ml})$ were also collected by vacuum filtration. Salt was removed by washing filters under vacuum with $10 \mathrm{ml} 4 \%$ ammonium formate. Filters were temporarily stored on dry ice, after which they were dried at $80^{\circ} \mathrm{C}$ for $48 \mathrm{~h}$, weighed, combusted at $450^{\circ} \mathrm{C}$ for $6 \mathrm{~h}$, and weighed again after cooling in a desiccator. The \% AE of organic matter ingested by the scallops was calculated according to Conover (1966): $\mathrm{AE}=(F-E) /[(1-E) \times F]$ $\times 100$, where $F$ and $E$ are the ash-free dry wt to dry wt ratios of the algae and feces, respectively. FDR was determined as: $\mathrm{FDR}=D F / t$, where $D F$ is the dry weight of feces produced and $t=$ time in feeding cham- bers. This value was standardized for a scallop of $1 \mathrm{~g}$ soft tissue weight.

Toxin extraction and analysis. Toxins from scallop tissues were extracted in $80 \%$ aqueous methanol using methods described by Quilliam (1995). The supernatant from the tissue homogenate was subjected to a liquid-liquid partitioning clean-up using hexane and $\mathrm{CHCl}_{3}$. Following evaporation of the $\mathrm{CHCl}_{3}$ phase, the residues were re-dissolved in $100 \%$ methanol and filtered through a $0.45 \mu \mathrm{m}$ cartridge-filter (Millipore Ultrafree-MC).

Toxin content of Prorocentrum lima cells was determined by removing $400 \mathrm{ml}$ of algae from the stock tank at $2 \mathrm{~d}$ intervals. Cells were counted and concentrated by centrifugation at $4000 \times g$ for $20 \mathrm{~min}\left(4^{\circ} \mathrm{C}\right)$. The wet weight of the pellet was determined, after which the algal cells were disrupted by $10 \mathrm{~s}$ bursts of probe sonication for $3 \mathrm{~min}$ in $10 \mathrm{vol}$ of methanol. Sonicated samples were centrifuged for $10 \mathrm{~min}$ at $4000 \times g\left(4^{\circ} \mathrm{C}\right)$ and the supernatant was centrifuged through a $0.45 \mu \mathrm{m}$ cartridge-filter.

After separation by liquid chromatography, toxins were analyzed using an API-III mass spectrometer (LC-MS) (SCIEX, Thornhill, Ontario) equipped with an ion-spray interface (Quilliam 1995). Toxin peaks (OA, DTX1, okadaic acid diolester [OADE]) were quantified by direct comparison of relative chromatogram peak areas with a certified OA standard (OACS-1, Certified Reference Material Program, National Research Council Canada). Each toxin was assumed to yield a molar response equal to that of OA. Individual toxin components were summed (OA + DTX1 + OADE) and expressed as total DSP toxin equivalents.

\section{RESULTS}

\section{Short-term feeding rates}

Within the 20 min feeding period of the experiment, no pseudofeces were produced at the cell concentrations tested and no feces were produced by juvenile Argopecten iriadians. Mean weight-standardized ( $1 \mathrm{~g}$ wet wt) CR of juvenile bay scallops exposed to volume equivalent cell densities of Thalassiosira weissflogii or Prorocentrum lima were $634 \mathrm{ml}$ $\mathrm{h}^{-1}(\mathrm{SD}=185)$ and $767 \mathrm{ml} \mathrm{h}^{-1}(\mathrm{SD}=149)$, respectively. There was no significant difference between the CR of the scallops when exposed to either alga (Student's $t$-test, $t=-1.25, \mathrm{df}=8, \mathrm{p}>0.05$ ). Scallops did not exhibit any unusual behaviour when exposed to $P$. lima, such as shell valve closure or violent clapping/swimming activity. Cell concentrations in the control beakers remained constant during the feed- 
ing period for both of the algal suspensions, indicating that cell depletion in the beakers containing scallops was due to scallop ingestion and not to settlement of cells.

CR of adult scallops exposed to Prorocentrum lima cells declined exponentially with increasing cell concentrations over a range of 36 to 426 cells $\mathrm{ml}^{-1}$ (Fig. 2a). Pseudofeces production was only observed at the highest $P$. lima cell concentration tested $(426$ cells $\mathrm{ml}^{-1}$ ); therefore, ingestion rates could not be calculated at this concentration since the number of cells rejected in pseudofeces would have to be determined. Maximum ingestion rates ( $\mathrm{CR} \times$ cell concentration) of $P$. lima cells occurred at cell concentrations of approximately 130 cells $\mathrm{ml}^{-1}$. CR of scallops fed equivalent biovolume concentrations of the non-toxic diatom Thalassiosira weissflogii also declined exponentially with increasing cell concentrations; however, $\log _{\mathrm{e}}-$ transformed regression equations indicated that the rate of decline was much less than for $P$. lima cells (Fig. 2b). Although there was no significant difference in CR of scallops exposed to the 2 algal diets at equivalent biovolume cell concentrations below 150 P. lima cells $\mathrm{ml}^{-1}$ ( $t$-test, $\mathrm{p}>0.05, \mathrm{n}=7$ ), $\mathrm{CR}$ were significantly lower for scallops exposed to $P$. lima at cell concentrations greater than 200 cells ml $^{-1}$ ( $t$-test, $\mathrm{p}<0.0001, \mathrm{n}=$ 7 ). The feeding behaviour of scallops appeared to be the same in both diets, except at the highest $P$. lima cell concentrations, when scallop valves were observed to shut frequently. (a)

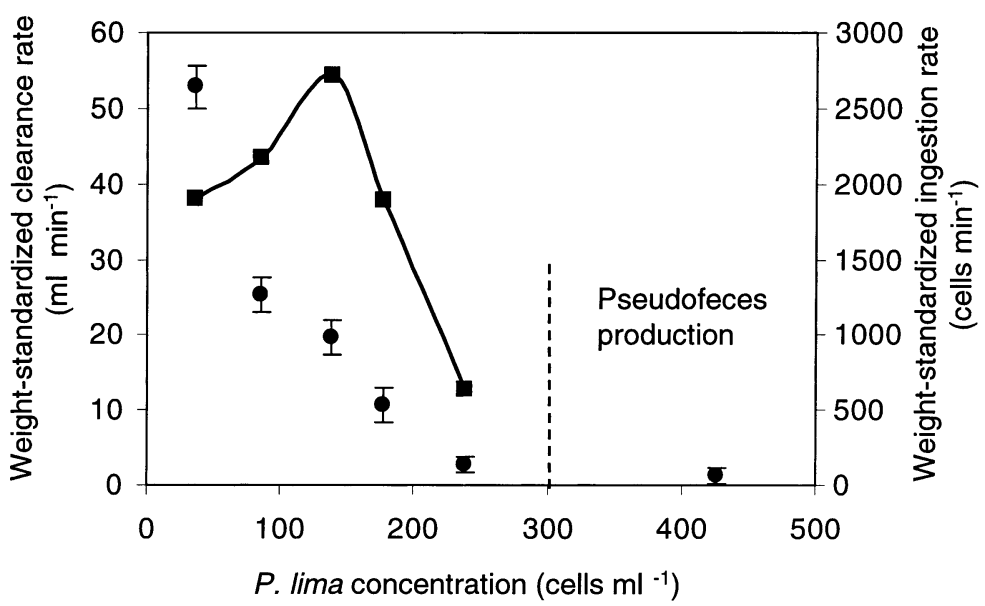

(b)

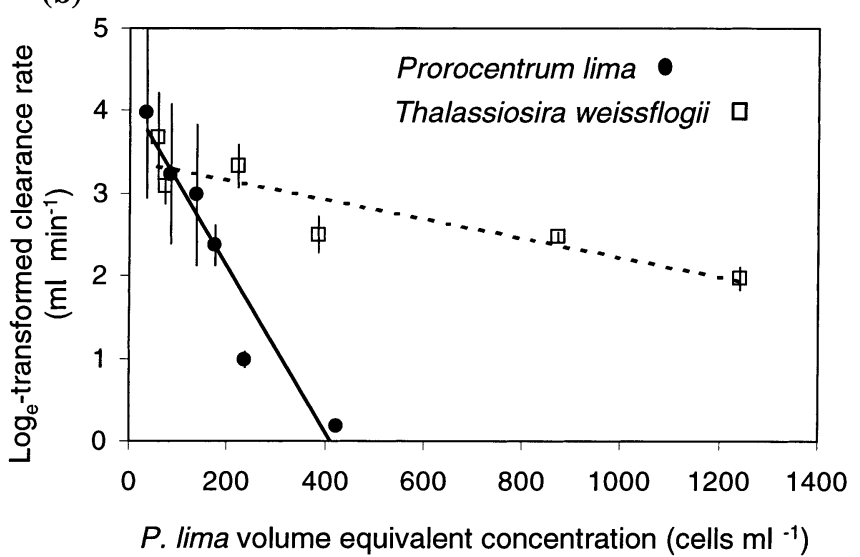

Fig. 2. Argopecten irradians. (a) Weight-standardized clearance ( $\mathbf{\square}$ ) and ingestion ( $)$ rates of Prorocentrum lima cells by A. irradians; error bars $= \pm \mathrm{SE}$ of 7 scallops; dashed line indicates cell concentration at which scallops began to produce pseudofeces. (b) Fitted linear regressions of $\log _{\mathrm{e}}$-transformed weight-standardized clearance rates for equivalent biovolume cell concentrations of $P$. lima: $y=4.13-(0.0100) x_{i} \mathrm{r}^{2}=0.92$, and Thalassiosira weissflogii: $y=3.40-(0.0012) X_{i} r^{2}=0.80$

\section{Tissue compartmentalization of toxins in adults}

After 2 d exposure to Prorocentrum lima cells, total DSP toxin concentrations were approximately $1 \mu \mathrm{g} \mathrm{g}^{-1}$ in visceral and gonadal tissues, and less than $0.1 \mu \mathrm{g} \mathrm{g}^{-1}$ in the gills, mantle and adductor muscle. Toxin concentrations were slightly greater in visceral than in gonadal tissues; however, this difference was not significant $(t$-test, $\mathrm{p}>$ 0.05). Although gills, mantle and adductor muscle comprised $71 \%$ of the soft tissue weight of the scallops (Fig. 3a), most of the TTBB was confined to the viscera (Fig. 3b). Gonadal tissue accounted for only $4 \%$ of the soft tissue weight in pre-reproductive scallops; however, $11 \%$ of the TTBB was present in the gonads.

\section{Feeding physiology}

Juvenile and adult scallops exhibited no apparent detrimental physiological responses during long-term exposure to toxigenic Prorocentrum lima. Scallops appeared to be actively feeding at all times (i.e. wide shell gape). Prolonged shell closure, shell clapping and violent swimming behaviour were not observed during the exposure period. Juveniles remained bysally attached to the tank walls throughout the experiment, indicating that byssus production and climbing behaviour were unaffected by exposure to $P$. lima. No mortalities occurred during the entire exposure period. 
(a)

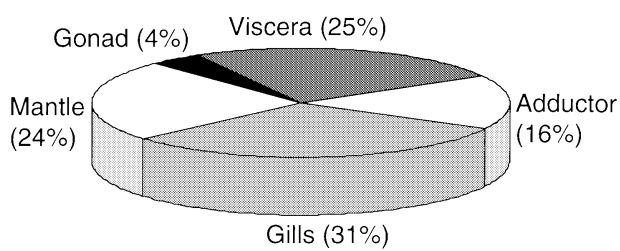

(b)

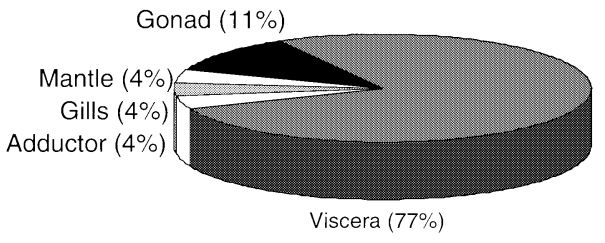

Fig. 3. Argopecten irradians. Contributions (\%) of tissue compartments to (a) total wet weight of soft tissues and (b) total body burden of DSP toxins (OA + DTX1 + OADE) in adults after $48 \mathrm{~h}$ exposure to toxigenic Prorocentrum lima cells tissue) mean of $325 \mu \mathrm{g}$ dry $\mathrm{wt} \mathrm{h}^{-1}(\mathrm{SD}=60)$ (Fig. $\left.4 \mathrm{c}\right)$. Intact $P$. lima cells were observed in scallop fecal ribbons when examined by microscopy (Bauder \& Cembella 2000).

\section{Toxin uptake kinetics}

Prorocentrum lima cell concentrations in the aquaria containing juvenile and adult scallops fluctuated around time-weighted means of 131 and 173 cells ml ${ }^{-1}$, respectively. Mean $P$. lima CTC was similar in the aquaria with juvenile (9.8 pg cell $\left.{ }^{-1}, \mathrm{SD}=11.2\right)$ and adult $\left(10.0 \mathrm{pg} \mathrm{cell}^{-1}, \mathrm{SD}=4.2\right)$ scallops; however, the variation was considerable (Fig. 5a). Linear regression analysis of cumulative weight-specific ingestion rates indicated that both juvenile and adult scallops readily ingested $P$. lima cells at a constant rate of $1.1 \times 10^{6}$ cells $\mathrm{d}^{-1} \mathrm{~g}^{-1}$ for most of the feeding study; however, adults ingested cells at much higher rates for the first $2 \mathrm{~d}$ of the experiment (Fig. 5b).
Weight-standardized CR of adult scallops varied significantly over the pre-exposure, exposure and detoxification period (1-way repeated-measures ANOVA, $\mathrm{p}=0.0148, \mathrm{n}=7$ ) (Fig. 4a). Pairwise multiple comparisons indicated that CR were significantly higher during the detoxification period than prior to exposure to Prorocentrum lima or during the first 3 $\mathrm{d}$ of the exposure period $(\mathrm{p}<0.05)$. There was no significant shift in $\mathrm{CR}$ when scallops were changed from a diet of Thalassiosira weissflogii (pre-exposure) to P. lima. CR increased during the second week of exposure and continued to climb during detoxification. There was no significant difference in the \% organic matter content of $P$. lima (mean $=80.4 \%, \mathrm{SD}=$ 4.6) or $T$. weissflogii cells over time (mean $79.0 \%, \mathrm{SD}=9.2)(t$-test $, \mathrm{p}>0.05, \mathrm{n}=5)$. However, the AE of organic matter by adults varied significantly over the course of the feeding study (1-way repeated-measures ANOVA on arcsine-transformed values, $\mathrm{p}=0.0003, \mathrm{n}=7$ ) (Fig. 4b). AE were significantly lower after $3 \mathrm{~d}$ of exposure to $P$. lima than at the beginning of the exposure period (Student-Newman-Keul's test, $\mathrm{p}<0.05, \mathrm{n}=7$ ). Although $\mathrm{AE}$ values appeared to increase during detoxification when scallops were returned to a diet of $T$. weissfloggi, this increase was not significant. FDR by scallops were not significantly different over the exposure period (1-way repeatedmeasures ANOVA, $p=0.0996, n=7$ ), fluctuating around a weight-standardized ( $1 \mathrm{~g}$ wet wt (a)

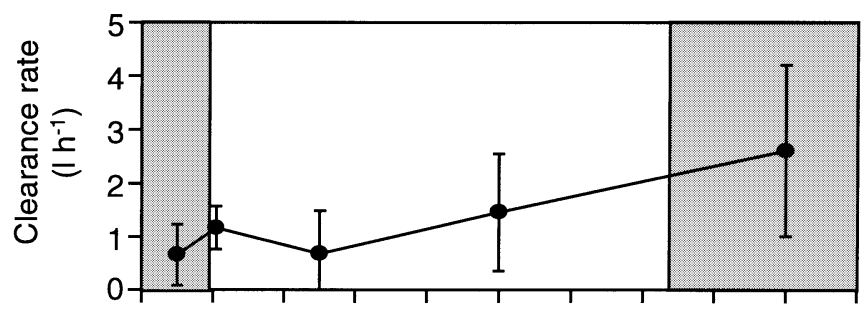

(b)

(c)
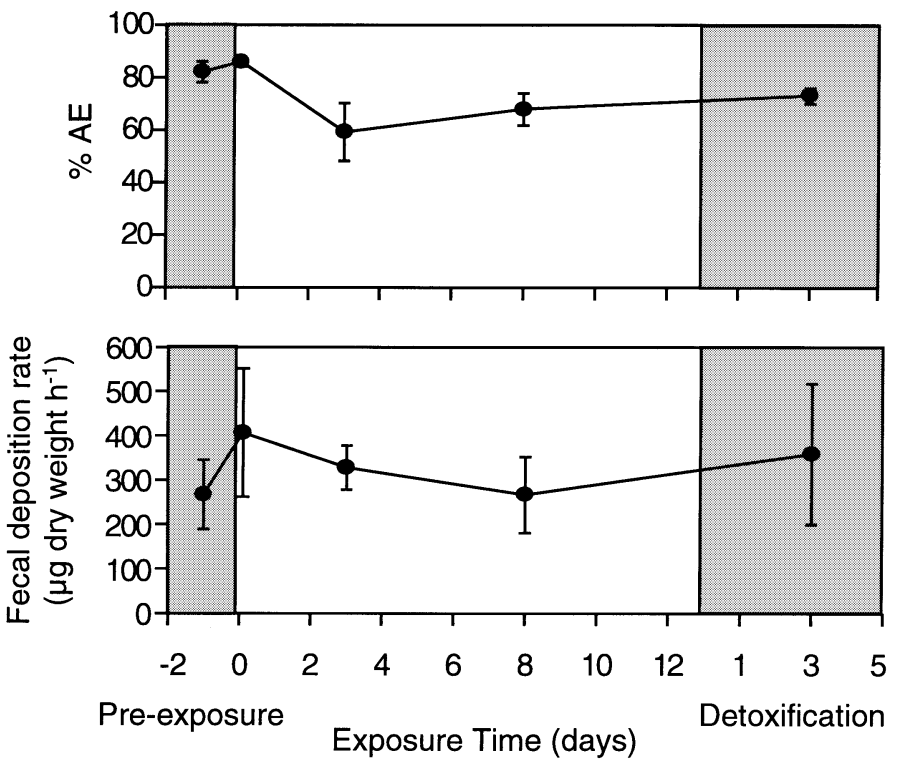

Fig. 4. Argopecten irradians. Physiological feeding indices during exposure to toxigenic Prorocentrum lima or non-toxic Thalassiosira weissflogii cells. (a) Weight-standardized clearance rate; (b) \% absorption efficiency $(\mathrm{AE})_{i}$ (c) weight-standardized fecal deposition rate. T. weissflogii was fed to scallops during pre-exposure and detoxification periods (shaded areas). Error bars $= \pm \mathrm{SE}$ of 7 scallops 
(a)

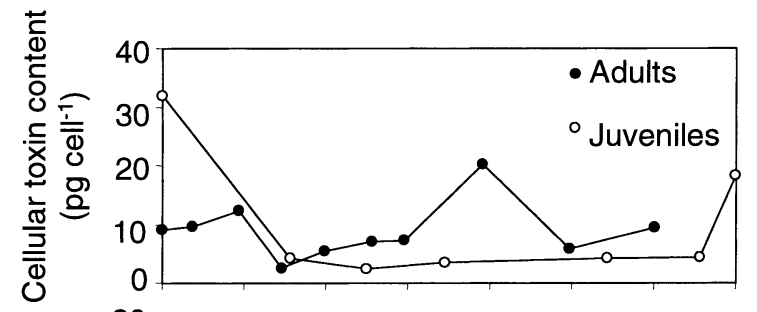

(b)

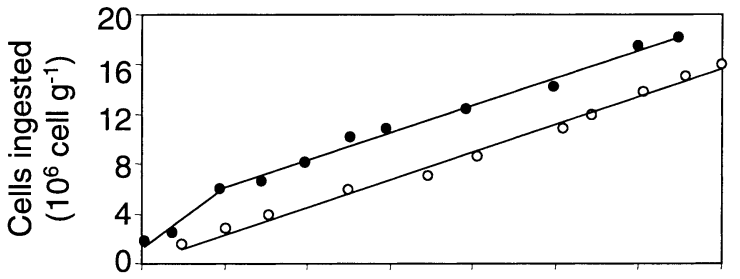

(c)

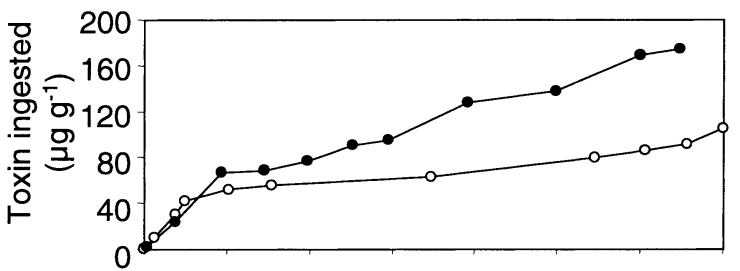

(d)

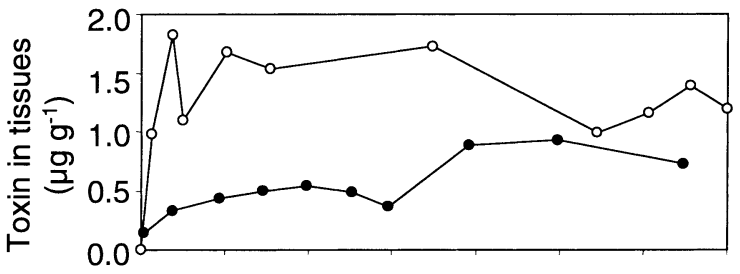

(e)

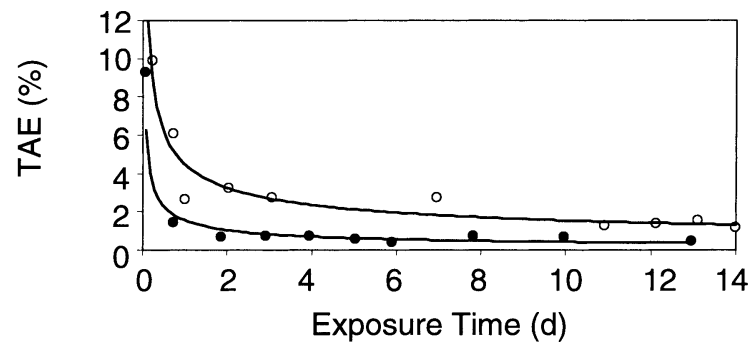

Fig. 5. DSP toxin kinetics in Argopecten irradians exposed to Prorocentrum lima cells during long-term feeding experiments. (a) DSP toxin (OA, DTX1, OADE) concentration of $P$. lima cells in aquaria containing juvenile and adult $A$. irradians. (b) Cumulative weight-specific ingestion rates of $P$. lima cells $\left(10^{6}\right.$ cells $\mathrm{g}^{-1}$ wet wt); lines indicate fitted linear regressions: $y=\left(1.12 \times 10^{6}\right) t_{i} \mathrm{r}^{2}=0.99$ (for juveniles), $y=\left(3.21 \times 10^{6}\right) t_{\text {; }}$ $\mathrm{r}^{2}=0.99$ (for adults during initial $2 \mathrm{~d}$ exposure) and, $y=3.89 \times$ $10^{6}+\left(1.10 \times 10^{6}\right) t_{i} \mathrm{r}^{2}=0.99$ (for adults during subsequent $11 \mathrm{~d}$ exposure). (c) Cumulative weight-specific ingestion rates of DSP toxins ( $\mu$ g DSP toxin $g^{-1}$ wet wt). (d) DSP toxin concentration in whole scallop tissue $\left(\mu \mathrm{g}\right.$ toxin $\mathrm{g}^{-1}$ wet wt). (e) DSP

toxin accumulation efficiency (TAE) in scallop tissues

Estimates of CTI by scallops by the end of the feeding study, based on cell ingestion rates and CTC, were $105 \mu \mathrm{g} \mathrm{g}^{-1}$ in juveniles and $175 \mu \mathrm{g} \mathrm{g}^{-1}$ in adults (Fig. 5c). As determined by LC-MS analysis, DSP toxin concentrations in whole scallop tissues never exceeded
$2 \mu \mathrm{g} \mathrm{g}^{-1}$ throughout the study (Fig. $5 \mathrm{~d}$ ). In both juvenile and adult scallops, the concentration of DSP toxins in the tissues was highly dependent upon the fluctuating toxin content of ingested Prorocentrum lima cells. For example, toxin concentrations in adult scallop tissue peaked on Day 8, coinciding with the peak in $P$. lima CTC.

TAE (\%) in scallop tissues decreased rapidly during the feeding study, from $10 \%$ of total toxin ingested after $6 \mathrm{~h}$ exposure to levels near $2 \%$ in juvenile and $<1 \%$ in adult tissues after $2 \mathrm{~d}$ (Fig. 5e). This relationship can be adequately described by the power function: $y=c x^{b}$. Although DSP TAE in scallop tissues were low, it should be noted that the widely accepted DSP toxin regulatory level of $0.2 \mathrm{\mu g} \mathrm{g}^{-1}$ whole tissue (Quilliam 1995) was surpassed in both juvenile and adult scallops within the initial $18 \mathrm{~h}$ of exposure to Prorocentrum lima.

\section{Toxin uptake and loss in tissue compartments}

In juvenile scallops, toxin concentrations were far greater in scallop visceral tissue (mean $=4.39 \mathrm{\mu g} \mathrm{g}^{-1}$, $\mathrm{SD}=0.86$ ) than in the gills, mantle and adductor combined (mean $=0.28 \mu \mathrm{g} \mathrm{g}^{-1}, \mathrm{SD}=0.19$ ). The mean tissue contribution to total wet weight in the scallops for viscera and all other tissues was 27 and $73 \%$, respectively. However, the contribution of these tissues to TTBB was essentially reversed, with viscera and all other tissues comprising 85 and $15 \%$, respectively.

In adult scallops, temporal patterns of DSP toxin uptake in viscera, gonad and other tissues (mantle, gills and adductor muscle) were similar, although toxin uptake rates were greatest in visceral and gonadal tissue (Fig. 6). Pearson product-moment correlations indicated that toxin concentrations in each of the tissue compartments were significantly correlated during the toxin uptake period $(p<0.05)$. Over the course of the uptake period, toxin concentrations in each of the tissue compartments followed the same rank order: viscera > gonads $\gg$ other tissues. Tissue wet weights, expressed as percentage of total body weight, remained constant throughout the uptake and detoxification periods. During the uptake period, visceral tissue comprised most $(76 \%)$ of the TTBB, while gonadal and other tissues accounted for 11 and $13 \%$, respectively (Fig. 7). During the first $2 \mathrm{~d}$ of detoxification, visceral tissue represented $96 \%$ of TTBB, after which virtually the entire remaining toxin load was confined to this tissue.

Detoxification in all tissues followed an exponential pattern; however, toxin release was far more rapid from gonads and other tissues than from the viscera (Fig. 8). Detoxification data were fitted to the general exponential loss equation: $T_{t}=T_{0} \mathrm{e}^{-\lambda t}$, where $T_{0}=$ toxin concen- 


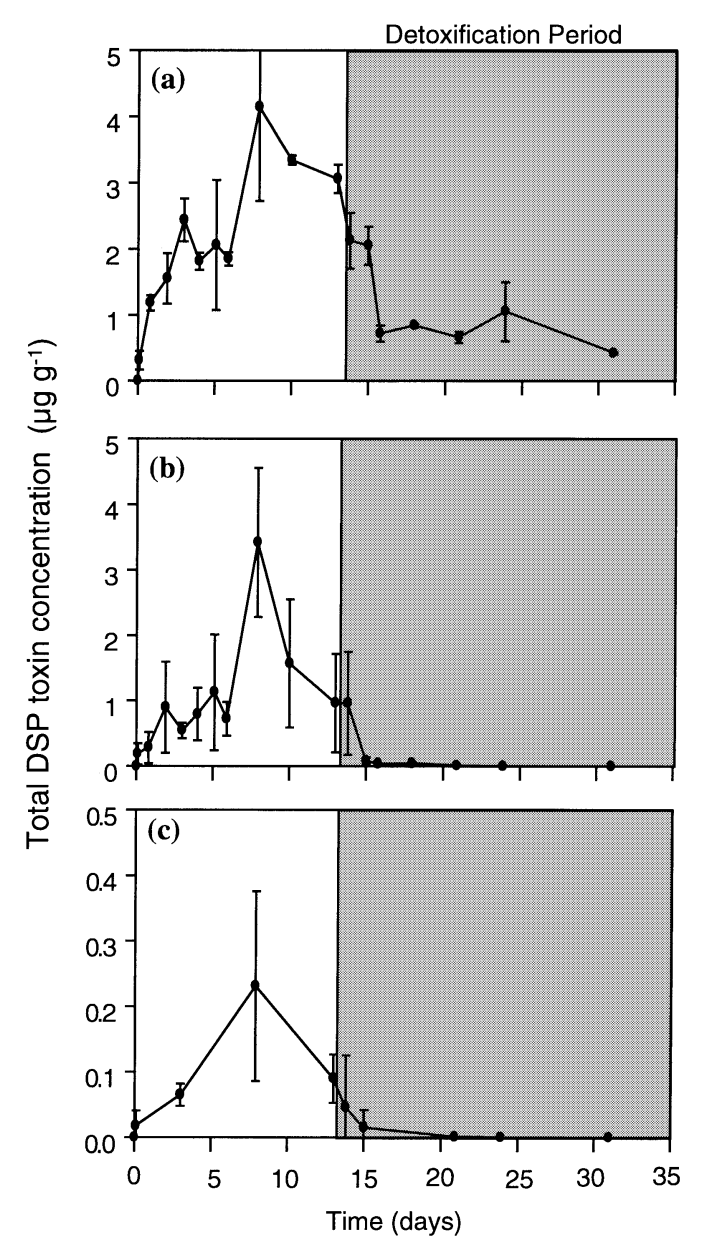

Fig. 6. Argopecten irradians. Uptake and loss of DSP toxins in (a) viscera tissue, (b) gonad tissue, and (c) other tissues (gill, mantle, adductor muscle) during exposure to Prorocentrum lima cells (mean concentration $=173$ cells ml ${ }^{-1}$ ), followed by detoxification (shaded area) on a diet of Thalassiosira weissflogii $\left(2500\right.$ cells $\left.\mathrm{ml}^{-1}\right)$. Error bars $= \pm \mathrm{SE}$ of 3 scallops

tration at start of detoxification, $\lambda=$ exponential decay coefficient and $t=$ time (d). Toxin loss from the viscera appeared to follow a biphasic pattern, characterized by a rapid release of toxins during the initial $3 \mathrm{~d}$ of detoxification ( $77 \%$ of the original toxin load). This was followed by much more gradual detoxification over the ensuing weeks, although a higher sampling frequency would be required to confirm this pattern. While toxin loss from visceral tissue was calculated to be $8.4 \% \mathrm{~d}^{-1}$, gonads and other tissues detoxified far more rapidly, at rates of 50 and $68 \% \mathrm{~d}^{-1}$, respectively. Toxin levels in gonads and other tissues were undetectable within $5 \mathrm{~d}$ of detoxification; however, toxin concentrations in visceral tissues still remained at levels above regulatory limits $\left(0.2 \mu \mathrm{g} \mathrm{g}^{-1}\right.$ whole tissue or ca $1 \mu \mathrm{g} \mathrm{g}^{-1}$ viscera $)$ after $11 \mathrm{~d}$ of detoxification. No DSP toxins were detected in visceral tissues after 2 mo of detoxification.

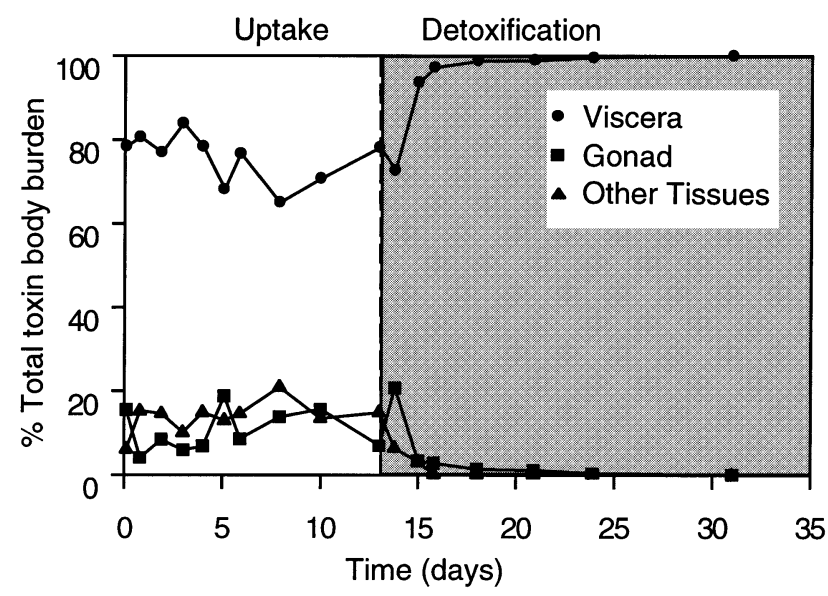

Fig. 7. Argopecten irradians. Contributions (\%) of tissue compartments to total DSP-toxin body burden in adults during exposure to toxigenic Prorocentrum lima cells (mean concentration $=173$ cells $\mathrm{ml}^{-1}$ ) and during detoxification period (shaded area)

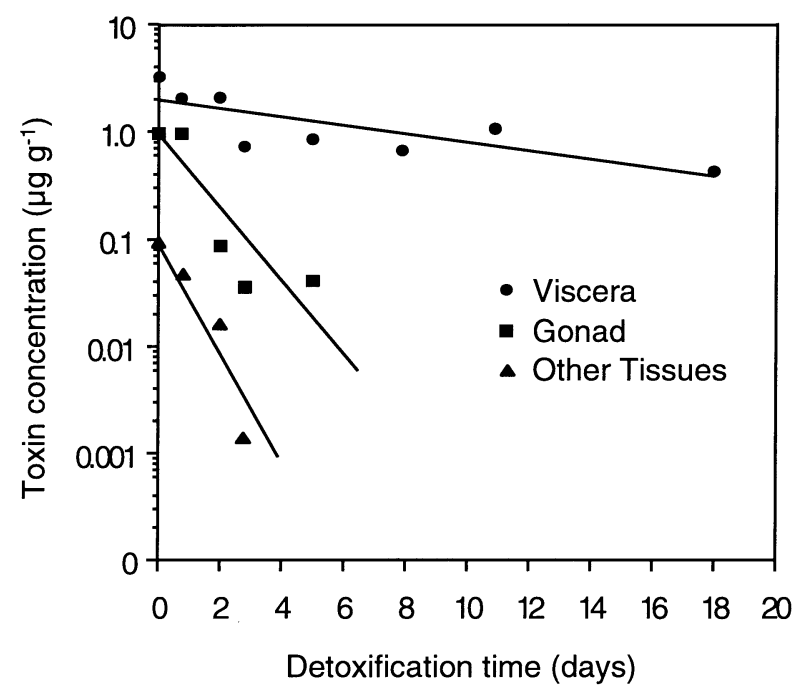

Fig. 8. Argopecten irradians. Loss of DSP toxins from tissue compartments. Detoxification rates fitted to the general exponential loss equation: $T_{t}=T_{0} \mathrm{e}^{-\lambda t}$, where $T_{0}=$ toxin concentration at beginning of detoxification period $\left(\mu \mathrm{g} \mathrm{g}^{-1}\right), \lambda=$ exponential decay coefficient $\left(\% \mathrm{~d}^{-1}\right)$ and $t=$ time $(\mathrm{d})$. Viscera: $T_{t}=$ $1.87 \mathrm{e}^{-0.088 t}, \mathrm{r}^{2}=0.62$; gonads: $T_{t}=0.96 \mathrm{e}^{-0.684 t}, \mathrm{r}^{2}=0.80$; others: $T_{t}=0.09 \mathrm{e}^{-1.137 t}, \mathrm{r}^{2}=0.90$

\section{DISCUSSION}

\section{Feeding physiology}

OA and its derivatives are powerful cytotoxins that block dephosphorylation of proteins in a broad range of animals and plants (reviewed in Aune \& Yndestad 1993). As noted by Windust et al. (1996), there is very little known regarding the effect of these compounds 
on marine animals. Svensson \& Forlin (1998) recently reported that OA caused limited inhibition of protein phosphatase activity in the digestive tissue of Mytilus edulis; however, glycogen synthase activity was unaffected. Interestingly, the activity of both enzymes was significantly inhibited in the liver of the rainbow trout Oncorhynchus mykiss when exposed to OA, prompting the authors to suggest that $M$. edulis may use protective mechanisms to survive the harmful effects of DSP toxins. In the present study, exposure to DSP-producing Prorocentrum lima cells had no adverse effects on survival and feeding of Argopecten irradians. CR of bay scallops feeding on $P$. lima were comparable to those reported in other studies of $A$. irradians ingesting non-toxic diatom cells at similar biovolume concentrations (Palmer 1980, Peirson 1983, Bricelj \& Kuenstner 1989, Bricelj \& Shumway 1991).

The results of the present study, suggesting that bay scallops are not affected by exposure to DSP toxigenic cells, imply that these animals are able to protect themselves from the effects of the toxins. Shumway \& Cucci (1987) postulated that when bivalves are exposed to toxigenic algal cells, they will often cope with the toxin either by closing their valves, thereby arresting feeding activity completely, or by employing feeding mechanisms to reduce the amount of toxin accumulated. Pre-ingestive methods to reduce ingestion of toxic cells would include reduced filtration rates or rejection of cells as pseudofeces. Throughout the long-term feeding studies, bay scallops exhibited neither of these strategies when exposed to Prorocentrum lima; however, at concentrations greater than ca 300 cells $\mathrm{ml}^{-1}$, pseudofeces production by adult scallops was observed and CR were significantly reduced relative to the non-toxic control diet. Similar results were reported by Pillet \& Houvenaghel (1995), who noted that Mytilus edulis feeding rates were lower for toxic $P$. lima cells than for non-toxic P. micans at concentrations of 1000 cells $\mathrm{ml}^{-1}$; however, there were no differences at 100 cells $\mathrm{ml}^{-1}$. A possible hypothesis is that a threshold concentration of $P$. lima cells must be reached to trigger scallops into reducing $\mathrm{CR}$ as a defensive feeding mechanism. Scallops may sense $P$. lima metabolites in the surrounding water only when exposed to cells in high concentrations, or perhaps mucilage associated with high concentrations of $P$. lima cells simply interferes with scallop feeding mechanisms.

Post-ingestive feeding mechanisms used by bivalves to select for and against ingested particles were demonstrated by Shumway et al. (1985) using flowcytometric methods to examine cell composition in fecal ribbons. Although the oyster Ostrea edulis preferentially ingested Prorocentrum minimum cells relative to other microalgal species, these authors argued that the high incidence of $P$. minimum fragments and intact cells in the fecal ribbons indicated that these cells were selectively rejected from the oyster's gut. Post-ingestive strategies by bay scallops are proposed here to reduce DSP toxin absorption when exposed to $P$. lima as a food source. Evidence for post-ingestive rejection of $P$. lima cells is provided by the presence of intact cells in fecal ribbons (Bauder \& Cembella 2000) and by the observed decrease in AE exhibited by adult bay scallops following a change of diet from Thalassiosira weissflogii to $P$. lima. While AE of bay scallops feeding on $T$. weissflogii cells were remarkably similar to those reported by Peirson (1983) and by Bricelj \& Kuenstner (1989) for Argopecten irradians feeding on the same diatom species, the lower AE for $P$. lima cells resembled those of scallops exposed to cells of poorer nutritive quality than T. weissflogii (Peirson 1983). Cranford \& Grant (1990) noted that AE values for sea scallops were correlated with the organic matter content of the ingested food. Since P. lima and T. weissflogii were determined to be equal in relative organic matter content $(80 \%)$, the decrease in $\mathrm{AE}$ during $P$. lima exposure was likely to have been a result of $P$. lima cells being less digestible than the diatoms. The rapid increase in $\mathrm{CR}$ exhibited when adult scallops were depurated on a diet of non-toxic diatoms may have been an attempt by the scallops to compensate for nutritional losses incurred during exposure to $P$. lima cells. This suggests that although scallops were able to survive 2 wk of exposure to toxigenic P. lima, longer toxin exposure might have resulted in nutritional deficiencies and poor growth.

\section{Toxin uptake and compartmentalization}

Although DSP toxin concentrations in shellfish tissue commonly surpass regulatory levels in Japan and Europe, where blooms of toxic Dinophysis spp. are common, levels rarely approach those reported for PSP toxin accumulation in bivalve tissue ( $>1000 \mu \mathrm{g}$ saxitoxin equivalents $\mathrm{g}^{-1}$ ) under natural conditions and during laboratory feeding studies (Bricelj \& Shumway 1998). Regulatory limits for DSP toxins in shellfish vary between countries, depending on the methods of analysis and the responsible authorites. In Canada, the DSP toxin tolerance level is unofficially recognized as $0.2 \mathrm{\mu g} \mathrm{g}^{-1}$ whole tissue (Shumway et al. 1995). Peak DSP toxin concentrations reported for bivalves exposed to natural blooms of Dinophysis spp. are usually in the range of 1 to $10 \mu \mathrm{g} \mathrm{g}^{-1}$ digestive gland tissue (Séchet et al. 1990, Della Loggia et al. 1993, Quilliam et al. 1993, Carmody et al. 1995, Haamer 1995). In the present study, bay scallop viscera tissue attained peak toxin levels at 3 to $6 \mu \mathrm{g} \mathrm{g}^{-1}$, which agrees very well with values reported in the literature. Thus, it appears 
that the low DSP TAE exhibited by bay scallops emulates feeding processes that occur in scallops and mussels during exposure to DSP-producing algae under natural conditions. These observations are supported by a field study conducted by Haamer et al. (1990), in which DSP toxin levels were much lower than expected for mussels feeding on Dinophysis spp. cells in a Swedish fjord. Haamer et al. suggested that OA avoidance mechanisms may operate in mussels, and hypothesized that these could include valve closure, reduced $\mathrm{CR}$, decreased absorption or rapid depuration. The results of the present study argue against a reduction in feeding as a toxin avoidance mechanism, and support the hypothesis that bivalves are able to maintain relatively low DSP toxin levels primarily via efficient elimination of intact Prorocentrum lima cells and associated DSP toxins.

Adult bay scallops accumulated DSP toxins at rates rapid enough to exceed the regulatory level $\left(0.2 \mu \mathrm{g} \mathrm{g}^{-1}\right.$ whole tissue) in less than $18 \mathrm{~h}$ exposure to Prorocentrum lima cells. However, since overall toxin-assimilation efficiency in scallop tissue was less than $1 \%$, the initial toxin load was probably a result of newly ingested $P$. lima cells in the gut (including the intestinal loop passing through the gonad). This point is further supported by the similarity between fluctuations in $P$. lima CTC and tissue toxin content in both the juvenile and adult feeding experiments. The close coupling of tissue toxin load with CTC strongly suggests that DSP toxicity in scallop tissue was mainly derived from labile (unbound) toxin components with a short residence time $(<1 \mathrm{~d})$ in scallop tissues. The labile toxin load would have been a result of both intact and recently digested $P$. lima cells, primarily confined to the scallop gut. Furthermore, this would account for both the relatively high toxin levels in gonadal tissue and low levels in mantle, gills and adductor, since the gonad includes part of the intestinal tract.

In juvenile and adult bay scallops, most of the DSP toxin load was confined to the viscera. Although toxin concentrations were relatively high in adult gonadal tissue, rapid detoxification rates again suggest that toxicity in the gonads was represented by a labile component confined to the intestinal tract, rather than bound to the tissue. This evidence agrees with observations for Mytilus edulis in which DSP toxin concentrations in digestive tissue were 7 (Vernoux et al. 1994) to 10 (Pillet et al. 1995) times greater than that of the other tissues. Elimination rates of DSP toxins were lower for the viscera than for all other tissues. This is in marked contrast to results obtained with PSP toxins, in which the viscera typically detoxify faster than other tissues (Bricelj \& Shumway 1998).

In bay scallops, DSP toxins were only bound to visceral tissue, as demonstrated during depuration by the slow loss of toxins from this compartment compared to all other tissues. During detoxification, significant toxicity would only be expected to be associated with visceral tissue, and possibly gonads during initial depuration, due to the inclusion of the intestine with this tissue. Although DSP toxins were not tightly incorporated with the gonadal tissues in this study, questions still remain pertaining to the kinetics of DSP toxins in scallop gonads during the various stages of the gametogenic cycle. For example, scallops may be more likely to incorporate lipophilic DSP toxins into the gonads during periods when a high proportion of food and energy reserves are utilized for gametogenesis. Moreover, the critical link between gamete production and energy derived from ingested food (Barber \& Blake 1991) warrants further investigation regarding the effect of DSP toxins on gametogenesis in scallops.

\section{Loss of DSP toxins}

Detoxification of the viscera was identified by an immediate and substantial loss of DSP toxins during the initial $3 \mathrm{~d}$ of depuration followed by a much slower loss over the subsequent weeks. Similar detoxification patterns have been observed for the loss of PSP toxins from Mytilus edulis (Silvert \& Cembella 1995) and Mercenaria mercenaria (Bricelj et al. 1990, 1991), prompting Silvert et al. (1998) to model this as a 2-stage process consisting of a rapid loss of labile toxins followed by a slow release of the bound fraction. Bricelj et al. (1991) used general exponential equations to describe the loss of PSP toxins from tissues of $M$. mercenaria. The same approach was employed in the present study to describe the release of DSP toxins from bay scallop tissues. Unfortunately, since other researchers have only reported loss of DSP toxins from shellfish in descriptive terms, it is difficult to compare data in the existing literature.

Depuration rates of DSP toxins calculated for bay scallop viscera compared well with those reported for the mussels Mytilus edulis (Yasumoto et al. 1978, Marcaillou-Le Baut et al. 1993b) and M. galloprovinciallis (Poletti et al. 1996) and for the Japanese scallop Patinopecten yessoensis (Tazawa et al. 1989, Kikuchi et al. 1992). Reported data of DSP toxin loss from $M$. edulis at aquaculture sites in Mahone Bay, Nova Scotia (Quilliam et al. 1993, Gilgan et al. 1995), were comparable to the detoxification of bay scallops in the present study. This similarity is significant, since the isolate of Prorocentrum lima used as the DSP toxin source in this study originated from Mahone Bay and is suspected to be the causative organism of DSP in that region (Lawrence et al. 1998). 
It should be noted that such comparisons must be made with caution due to the variety of toxin analysis methods used in these studies. Furthermore, it is difficult to compare detoxification rates among various bivalve species due to species-specific differences in feeding physiology, as shown for PSP toxin depuration studies (Bricelj \& Shumway 1998). Various studies have described very slow DSP detoxification rates for mussels under natural conditions. In Norway (Dahl \& Yndestad 1985, Underdal et al. 1985, Séchet et al. 1990) and Sweden (Haamer et al. 1990), low levels of DSP toxicity have been found to remain in mussel tissue throughout the winter following toxin uptake from exposure to blooms of Dinophysis spp. the previous autumn. Similar patterns of winter DSP toxin persistence have been reported for mussels from the Mediterranean coasts of Italy (Boni et al. 1993, Della Loggia et al. 1993) and France (Belin 1993).

Dahl \& Yndestad (1985) suggested that mussels were slow to detoxify due to low metabolic rates resulting from low temperatures and poor food conditions during the winter. Since low cell concentrations of Dinophysis spp. cells often occur sporadically during the winter (Underdal et al. 1985, Della Loggia et al. 1993), DSP toxin persistence in mussels may be a combined result of unusually efficient absorption of DSP toxins from ingested Dinophysis spp. cells and very slow gut clearance (and metabolic) rates due to low temperatures. This hypothesis was supported by Haamer's (1995) observation that mussels in Sweden detoxified most rapidly at the onset of the spring bloom, when high concentrations of non-toxic diatoms were once again available for mussel consumption.

\section{CONCLUSIONS}

This study has demonstrated that the epibenthic dinoflagellate Prorocentrum lima can act as a vector for DSP toxins in shellfish. In the bay scallop Argopecten irradians, toxigenic $P$. lima cells were ingested without any inhibitory effect on $\mathrm{CR}$, except at concen-

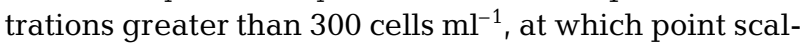
lops reduced feeding rates by intermittent valve closure and initiated pseudofeces production. During experiments lasting $2 \mathrm{wk}$, detrimental effects on feeding were not apparent in either adult or juvenile bay scallops during exposure to $P$. lima, nor were any mortalities observed, suggesting that DSP toxigenic algal blooms are likely to pose little threat to bay scallop populations. Possible longer-term effects of DSP toxins on scallop reproductive physiology should be investigated.

DSP toxin concentrations in bay scallop tissues surpassed accepted closure levels within $18 \mathrm{~h}$ of exposure to Prorocentrum lima cells, underscoring the potential for P. lima to cause DSP toxicity. Few studies have published densities of $P$. lima cells in the water column; however, Lawrence (1999) recently reported significant epiphytic growth of $P$. lima cells on macroalgae that foul mussels. Thus, $P$. lima cells dislodged from macroalgae, by wind or tide events, could be ingested by bivalves and result in rapid accumulation of DSP toxins.

After 2 wk exposure, overall DSP toxin retention was less than $1 \%$ of that ingested by the scallops. This suggests that scallops are able to prevent significant DSP toxin accumulation via efficient detoxification mechanisms. Furthermore, it does not appear that DSP toxins are easily bound to scallop tissues, with the exception of the viscera, which retained DSP toxins during $3 \mathrm{wk}$ of depuration. Gonadal tissues can become highly toxic during exposure to toxigenic microalgae. However, depuration rendered gonads free of toxins within $3 \mathrm{~d}$, indicating that DSP toxins were not sequestered in this tissue. In general, the results of the present study, as well as data reported in the literature, suggest that DSP toxins can be efficiently depurated from shellfish when these are exposed to a non-toxic food supply.

Acknowledgements. We thank Dr Jon Grant for useful advice and Larry Staples, Peter Shacklock, Steve McKenna, Gunter Morstatt, Nancy Lewis and Bill Hardstaff for technical assistance. Support for this study was provided in part by an NSERC scholarship to A.G.B.

\section{LITERATURE CITED}

Andersen P (1996) Design and implementation of some harmful algal monitoring systems. UNESCO, Paris (IOC Tech Ser No. 44)

Aune T, Yndestad M (1993) Diarrhetic shellfish poisoning. In: Falconer LA (ed) Algal toxins in seafood and drinking water. Academic Press, London, p 87-104

Barber BJ, Blake NJ (1991) Reproductive physiology. In: Shumway SE (ed) Scallops: biology, ecology and aquaculture. Elsevier, New York, p 377-428

Bardouil M, Bohec M, Cormerais M, Bougrier S, Lassus P (1993) Experimental study of the effects of a toxic microalgal diet on feeding of the oyster Crassostera gigas Thunberg. J Shellfish Res 12:417-422

Bauder AG (1997) Dynamics of diarrhetic shellfish toxins from the dinoflagellate Prorocentrum lima in the bay scallop Argopecten irradians. MSc thesis, Dalhousie University, Halifax

Bauder AG, Cembella AD (2000) Viability of the toxic dinoflagellate Prorocentrum lima following ingestion and gut passage in the bay scallop Argopecten irradians. J Shellfish Res 19:321-324

Bayne BL, Newell C (1983) Physiological energetics of marine molluscs. In: Saleuddin ASM, Wilbur KL (eds) The Mollusca, Vol 4. Physiology. Part I. Academic Press, New York, p 407-515

Belin C (1993) Distribution of Dinophysis spp. and Alexandrium minutum along French coasts since 1984 and their 
DSP and PSP toxicity levels. In: Smayda TJ, Shimuzu Y (eds) Toxic phytoplankton blooms in the sea. Elsevier, New York, p 469-474

Boni L, Milandri A, Poletti R, Pompei M (1993) DSP cases along the coast of Emilia-Romagna (northwestern Adriatic Sea). In: Smayda TJ, Shimuzu Y (eds) Toxic phytoplankton blooms in the sea. Elsevier, New York, p 475-481

Bricelj VM, Kuenstner SH (1989) Effects of the 'brown tide' on the feeding physiology and growth of bay scallops and mussels. In: Cosper EM, Bricelj VM, Carpenter EJ (eds) Novel phytoplankton blooms. Springer-Verlag, New York, p 491-509

Bricelj VM, Shumway SE (1991) Physiology: energy acquisition and utilization. In: Shumway SE (ed) Scallops: biology, ecology and aquaculture. Elsevier, New York, p 305-346

Bricelj VM, Shumway SE (1998) Paralytic shellfish toxins in bivalve molluscs: occurrence, transfer kinetics, and biotransformation. Rev Fish Sci 6:315-383

Bricelj VM, Lee JH, Cembella AD, Anderson DM (1990) Uptake kinetics of paralytic shellfish toxins from the dinoflagellate Alexandrium fundyense in the mussel Mytilus edulis. Mar Ecol Prog Ser 63:177-188

Bricelj VM, Lee JH, Cembella AD (1991) Influence of dinoflagellate toxicity on uptake and loss of paralytic shellfish toxins in the northern quahog Mercenaria mercenaria. Mar Ecol Prog Ser 74:33-46

Carmody EP, James KJ, Kelly SS, Thomas K (1995) Complex diarrhetic shellfish toxin profiles in Irish mussels. In: Lassus P, Arzul G, Erard E, Gentien P, Marcaillou C (eds) Harmful marine algal blooms. Lavoisier, Intercept Ltd, Paris, p 273-278

Cembella AD, Shumway SE, Larocque R (1994) Sequestering and putatative biotransformation of paralytic shellfish toxins by the sea scallop Placopecten magellanicus: seasonal and spatial scales in natural populations. J Exp Mar Biol Ecol 180:1-22

Chew KK (1990) Global bivalve shellfish introductions. World Aquacult 21:9-22

Conover RJ (1966) Assimilation of organic matter by zooplankton. Limnol Oceanogr 11:338-354

Coughlan J (1969) The estimation of filtering rate from the clearance of suspension. Mar Biol 2:356-358

Cranford PJ, Grant J (1990) Particle clearance and absorption of phytoplankton and detritus by the sea scallop Placopecten magellanicus (Gmelin). J Exp Mar Biol Ecol 137: 105-121

Dahl E, Yndestad M (1985) Diarrhetic shellfish poisoning (DSP) in Norway in the autumn 1984 related to the occurrence of Dinophysis spp. In: Anderson DM, White AW, Baden DG (eds) Toxic dinoflagellates. Elsevier, New York, p 495-500

Della Loggia R, Cabrini M, Del Negro P, Honsell G, Tubaro A (1993) Relationship between Dinophysis spp. in seawater and DSP toxins in mussels in the northern Adriatic Sea. In: Smayda TJ, Shimuzu Y (eds) Toxic phytoplankton blooms in the sea. Elsevier, New York, p 483-488

Gago A, de la Fuente E, Rodriguez JA, Ibaniez A (1991) DSP contaminated shellfish in Galician Rias along 1990. In: Frèmy JM (ed) Proceedings of symposium on marine biotoxins. Centre National d'Etudes Vétérinaires, Paris, p 225-227

Gilgan MW, Powell C, van de Riet J, Burns BG, Quilliam MA, Kennedy K MacKenzie CH (1994) The occurrence of a serious diarrhetic shellfish poisoning episode in mussels from Newfoundland during the late autumn of 1993. Can Tech Rep Fish Aquat Sci 2016:1-92
Gilgan MW, van de Riet J, Dorey M, Burns BG (1995) The detection of a DSP contamination of cultured mussels from Nova Scotia, Canada by bioassay, immunoassay and chemical assay. In: Lassus P, Arzul G, Erard E, Gentien P, Marcaillou C (eds) Harmful marine algal blooms. Lavoisier, Intercept Ltd, Paris, p 291-296

Guillard RL, Ryther JH (1962) Studies of marine planktonic diatoms. Can J Microbiol 8:229-239

Haamer J (1995) Presence of the phycotoxin okadaic acid in mussels (Mytilus edulis) in relation to nutrient composition in a Swedish coastal water. J Shellfish Res 14:209-216

Haamer J, Andersson PO, Lange S, Li XP, Edebo L (1990) Effects of transplantation and reimmersion of mussels Mytilus edulis Linnaeus, 1728, on their contents of okadaic acid. J Shellfish Res 9:109-112

Hageltorn M (1989) Algal toxins contaminating shellfish and shellfish monitoring in Sweden. In: Natori S, Hashimoto K, Ueno Y (eds) Mycotoxins and phycotoxins '88. Elsevier, Amsterdam, p 289-294

Hildreth DI, Crisp DJ (1976) A corrected formula for calculation of filtration rate of bivalve molluscs in an experimental flowing system. J Mar Biol Assoc UK 56:111-120

ICES (1992) Effects of harmful algal blooms on mariculture and marine fisheries. Cooperative research report no. 181. International Council for the Exploration of the Sea, Copenhagen, p 38

Kat M (1985) Dinophysis acuminata blooms. The distinct cause of Dutch mussel poisoning. In: Anderson DM, White AW, Baden DG (eds) Toxic dinoflagellates. Elsevier, New York, p 73-77

Keller MD, Selvin RC, Claus W, Guillard RL (1985) Factors significant to marine dinoflagellate culture. In: Anderson DM, White AW, Baden DG (eds) Toxic dinoflagellates. Elsevier, New York, p 113-116

Kikuchi S, Oshima T, Oshima Y, Takeuchi T, Nakamura T, Tatewaki M (1992) Decrease of shellfish toxins during the cultivation of toxic scallops in filtered and sterilized seawater. J Food Hyg Soc Jpn 33:223-230

Lawrence JL (1999) Population dynamics and toxicity of the epiphytic dinoflagellate Prorocentrum lima in a shallow coastal embayment: implications for shellfish aquaculture. PhD thesis, Dalhousie University, Halifax

Lawrence JL, Bauder AG, Quilliam MA, Cembella AD (1998) Prorocentrum lima: a putative link to diarrhetic shellfish poisoning in Nova Scotia, Canada. In: Reguera B, Blanco J, Fernandez ML, Wyatt T (eds) Harmful algae. Xunta de Galicia and IOC of UNESCO, Vigo, p 78-79

Marcaillou-Le Baut C, Bardin B, Bardouil M, Bohec M, Le Dean L, Masselin P, Truquet P (1993a) DSP depuration rates of mussels reared in a laboratory and an aquaculture pond. In: Smayda TJ, Shimuzu Y (eds) Toxic phytoplankton blooms in the sea. Elsevier, New York, p 531-535

Marcaillou-Le Baut C, Delmas D, Herbland A, Gentien P, Maestrini SY, Lassus P, Masselin P (1993b) Cinétique de contamintaion de moules Mytilus edulis exposees à une population naturelle de dinoflagellés Dinophysis spp. C R Hebd Séanc Acad Sci, Paris (Life Sciences) 316: 1274-1276

Palmer RE (1980) Behavioral and rhythmic aspects of filtration in the bay scallop, Argopecten irradians concentricus (Say), and the oyster, Crassostrea virginica (Gmelin). J Exp Mar Biol Ecol 45:273-295

Peirson WM (1983) Utilization of eight algal species by the bay scallop, Argopecten irradians concentricus (Say). J Exp Mar Biol Ecol 68:1-11

Pillet S, Houvenaghel G (1995) Influence of experimental toxification by DSP producing microalgae, Prorocentrum lima, on clearance rate in blue mussels Mytilus edulis. In: 
Lassus P, Arzul G, Erard E, Gentien P, Marcaillou C (eds) Harmful marine algal blooms, Lavoisier, Intercept Ltd, Paris, p 481-486

Pillet S, Pereira A, Braekman JC, Houvenaghel G (1995) Patterns in long-term accumulation of okadaic acid and DTX1 in blue mussels, Mytilus edulis, experimentally fed with the DSP-containing alga Prorocentrum lima. In: Lassus $\mathrm{P}$, Arzul G, Erard E, Gentien P, Marcaillou C (eds) Harmful marine algal blooms. Lavoisier, Intercept Ltd, Paris, p 487-492

Poletti R, Viviani R, Casadei C, Lucentini L, Giannetti L, Funari E Draisci R (1996) Decontamination dynamics of mussels naturally contaminated with diarrhetic toxins relocated to a basin of the Adriatic Sea. In: Yasumoto T, Oshima Y, Fukuyo Y (eds) Harmful and toxic algal blooms. Intergovernmental Oceanographic Commission of UNESCO, Paris, p 429-432

Quilliam MA (1995) Analysis of diarrhetic shellfish poisoning toxins in shellfish tissue by liquid chromatography with fluorometric and mass spectrometric detection. AOAC Int 78:555-570

Quilliam MA, Gilgan MW, Pleasance S, deFreitas ASW, Douglas D, Fritz L, Hu T, Marr JC, Smyth C, Wright JLC (1993) Confirmation of an incident of diarrhetic shellfish poisoning in eastern Canada. In: Smayda TJ, Shimuzu Y (eds) Toxic phytoplankton blooms in the sea. Elsevier, New York, p 547-552

Reguera B, Bravo I, Marciallou-Le Baut C, Masselin P, Fernandez ML, Miguez A, Martinez A (1993) Monitoring of Dinophysis spp. and vertical distribution of okadaic acid on mussel rafts in Ria de Ponteverda (NW Spain). In: Smayda TJ, Shimuzu Y (eds) Toxic phytoplankton blooms in the sea. Elsevier, New York, p 553-558

Rhodes EW (1991) Fisheries and aquaculture of the bay scallop, Argopecten irradians, in the eastern United States. In: Shumway SE (ed) Scallops: biology, ecology and aquaculture. Elsevier, New York, p 913-924

Rodriguez JA, Martinez AG, Oshima Y, Sugino K, Lee JS, Yasumoto T (1989) Analysis of toxins in mussels from the Atlantic coast of Spain. In: Natori S, Hashimoto K, Ueno Y (eds) Mycotoxins and phycotoxins '88. Elsevier, Amsterdam, p 367-374

Séchet V, Safran P, Hovgaard P, Yasumoto T (1990) Causative species of diarrhetic shellfish poisoning (DSP) in Norway. Mar Biol 105:269-274

Shumway SE (1990) A review of the effects of algal blooms on shellfish and aquaculture. J World Aquacult 21:65-104

Shumway SE, Cembella AD (1993) The impact of toxic algae on scallop culture and fisheries. Rev Fish Sci 1:121-150

Shumway SE, Cucci TL (1987) The effects of the toxic dinoflagellate Protogonyaulax tamarensis on the feeding and behaviour of bivalve molluscs. Aquat Toxic 10:9-27

Shumway SE, Cucci TL, Newell RC, Yentsch CM (1985) Particle selection, ingestion, and absorption in filter-feeding bivalves. J Exp Mar Biol Ecol 91:77-92

Shumway SE, van Egmond HP, Hurst JW, Bean LL (1995) Management of shellfish resources. In: Hallegraeff GM, Anderson DM, Cembella AD (eds) Manual on harmful

Editorial responsibility: Otto Kinne (Editor),

Oldendorf/Luhe, Germany marine microalgae. IOC Manuals and Guides No. 33. UNESCO, Paris, p 433-462

Silvert WL, Cembella AD (1995) Dynamic modeling of phycotoxin kinetics in marine invertebrates. Can J Fish Aquat Sci 52:521-531

Silvert WL, Bricelj M, Cembella A (1998) Dynamic modelling of PSP toxicity in the surfclam (Spisula solidissma): multicompartmental kinetics and biotransformation. In: Reguera B, Blanco J, Fernandez ML, Wyatt T (eds) Harmful algae. Xunta de Galicia and IOC of UNESCO, Vigo, p 437-440

Svensson S, Forlin L (1998) Effects of okadaic acid on protein phosphatase and glycogen synthase activities in blue mussel, Mytilus edulis, and rainbow trout, Oncorhynchus mykiss. In: Reguera B, Blanco J, Fernandez ML, Wyatt T (eds) Harmful algae. Xunta de Galicia and IOC of UNESCO, Vigo, p 584-587

Tazawa T, Ishige M, Kawase S, Ito T, Satoh N (1989) Seasonal variations of diarrhetic shellfish poison in scallops from the Okhotsk Sea coast of northern Hokkaido. Rep Hokkaido Inst Publ Health 39:81-83

Underdal B, Yndestad M, Aune T (1985) DSP intoxication in Norway and Sweden, autumn 1984-spring 1985. In: Anderson DM, White AW, Baden DG (eds) Toxic dinoflagellates. Elsevier, New York, p 489-494

van Egmond HP, Aune T, Lassus P, Speijers GJA, Waldock M (1993) Paralytic and diarrhoeic shellfish poisons: occurrence in Europe, toxicity, analysis and regulation. J Nat Toxins 2:41-83

Vernoux, JP, Bansard S, Simon JF, Nwal-Amang D, Le-Baut C, Gleizes E, Fremy JM, Lasne MC (1994) Cooked mussels contaminated by Dinophysis sp.: a source of okadaic acid. Nat Toxins 2:184-188

Windust AJ, Wright JLC, McLachlan JL (1996) The effects of the diarrhetic shellfish poisoning toxins, okadaic acid and dinophysistoxin-1, on the growth of microalgae. Mar Biol 126:19-25

Wright JLC, Cembella AD (1998) Ecophysiology and biosynthesis of polyether marine biotoxins. In: Anderson DM, Cembella AD, Hallegraeff GM (eds) Physiological ecology of harmful algal blooms. Springer-Verlag, Berlin, p 427-451 (NATO ASI Ser, G 41)

Yasumoto $\mathrm{T}$ (1990) Marine microrganisms toxins: an overview. In: Granelli E, Sundstrom B, Edler L, Anderson DM (eds) Toxic marine phytoplankton. Elsevier, New York, p 3-8

Yasumoto T, Oshima Y, Yamaguchi M (1978) Occurrence of a new type of shellfish poisoning in the Tohoku District. Bull Jpn Soc Sci Fish 44:1249-1255

Yasumoto T, Murata M, Lee JS, Torigoe K (1989) Polyether toxins produced by dinoflagellates. In: Natori S, Hashimoto $\mathrm{K}$, Ueno $\mathrm{Y}$ (eds) Mycotoxins and phycotoxins '88. Elsevier, Amsterdam, p 375-382

Zhao J, Lembeye G, Cenci G, Wall B, Yasumoto T (1993) Determination of okadaic acid and dinophysistoxin-1 in mussels from Chile, Italy and Ireland. In: Smayda TJ, Shimuzu Y (eds) Toxic phytoplankton blooms in the sea. Elsevier, New York, p 587-592

Submitted: October 18, 1999; Accepted: June 15, 2000

Proofs received from author(s): March 5, 2001 